\title{
sciendo
}

\section{PRE-SLAUGHTER HANDLING IMPLICATIONS ON RABBIT CARCASS AND MEAT QUALITY - A REVIEW}

\author{
Joanna Składanowska-Baryza*, Marek Stanisz
}

\author{
Department of Animal Breeding and Product Quality Assessment, Faculty of Veterinary Medicine \\ and Animal Science, Poznań University of Life Sciences, Złotniki, Słoneczna 1, \\ 62-002 Suchy Las, Poland \\ •Corresponding author: joanna.skladanowska-baryza@up.poznan.pl
}

\begin{abstract}
Procedures that result in poor welfare of animals are unacceptable to many people. Consumers have become demanding about the quality of meat, but are also concerned about animal welfare during the production, transport, and slaughter stages. There is a well-known, clear relationship between animal welfare and the quality of animal products. Improper handling of farmed animals contributes to low meat quality. This rule refers to all animals raised for meat, including rabbits. Fasting, loading for transport, long distance transport in difficult environmental conditions, improper stocking density, lying down during transport, lairage, and stunning methods may negatively affect the quality of rabbit meat. A general conclusion from reviewed scientific articles is that many pre-slaughter factors influence the physiological and productive measurements of rabbits, through the effect on their welfare. Because of the complexity of the rabbit meat production chain, the possibility of excluding all the defined stressors is limited.
\end{abstract}

Key words: meat quality, rabbit meat, welfare

Animal production takes into account animal welfare requirements. Numerous publications clearly show consumer interest in the welfare of farmed animals. There is a clear, indisputable relationship between animal health and the quality of animal products. The concept of welfare is ambiguous and defined in various ways. According to Hughes (1976), it is a state of complete mental and physical health, in which the animal remains in harmony with the surrounding environment. The increased interest in the production and consumption of rabbit meat, justifies the need to examine the stressors connected with the pre-slaughter procedures. Changes in the preslaughter handling system can improve rabbit welfare. The essential aspect during the entire ante-mortem period, as well as during the slaughter of animals, should be to limit their suffering (Doktor, 2007). Positive and negative factors, including: effi- 
cient loading and unloading, safe transport (not causing injury and loss), pre-slaughter fasting, stunning, and slaughtering significantly affect animal welfare and the quality of rabbit meat. All these activities influence the slaughtering performance, colour, $\mathrm{pH}$ and other aspects, determining the quality of the obtained carcasses (Voslarova et al., 2018; Buil et al., 2004; Mazzone et al., 2010). The aim of this paper was to analyse the effect of pre-slaughter conditions on the welfare and meat quality of commercial rabbits, under industrial schemes. The discussed problems, emphasised in scientific research, are named in Table 1.

Table 1. Effect of pre-slaughter stressor influencing meat quality and welfare of rabbit meat

\begin{tabular}{l|c|l}
\hline \multicolumn{1}{c|}{ Author } & \multicolumn{1}{c|}{ Stressor } & \multicolumn{1}{c}{ Effect } \\
\hline 1 & \multicolumn{1}{c}{2} & \multicolumn{1}{c}{3} \\
\hline $\begin{array}{l}\text { Jolley (1990) } \\
\text { Dalle Zotte (2002) }\end{array}$ & Fasting & $\begin{array}{l}\text { affects the quality of meat (ultimate muscle } \mathrm{pH} \text { ) } \\
\text { carcass yield (live weight losses) } \\
\text { safety of meat (spoilage and pathogenic bacteria) } \\
\text { carcass contamination, animal welfare }\end{array}$
\end{tabular}

Mazzone et al. (2010) Loading method

Lambertini et al. (2006) Travel time

Trocino et al. (2003) Travel time

Dal Bosco et al. (1997) Travel time

Liste et al. (2008) Travel time

María et al. (2006) Travel time

Voslarova et al. (2018) Travel distance

Buil et al. (2004) Stocking density

Buil et al. (2004) Lying during transport

De la Fuente et al. (2007) Noise

Liste et al. (2008)

Seasonality and environmental conditions

De la Fuente et al. (2007) Seasonality and environmental conditions carcasses loaded with the smooth method were characterised by smaller weight losses and higher dressing percentage compared to the rabbit loaded with the rough method

affected the live weight losses

6-8 hours transport might lead to dehydration of rabbits

carcasses exposed to longer transport characterised with a higher $\mathrm{pH}$, increased darkness and redness, compared to meat of rabbits transported for a shorter time

transport time ( $1 \mathrm{~h}$ and $7 \mathrm{~h}$ ) affected the blood level of corticosterone and $\mathrm{CK}$

significant effect on the meat texture parameters did not affect the shear force and toughness

the highest mortality was recorded for distances exceeding $400 \mathrm{~km}$

minimum floor space for 12-week-old rabbits should be $1800 \mathrm{~cm}^{2}$

cage position during transport may also negatively affect the welfare of transported rabbits

rabbits exposed to noise for $4.5 \mathrm{~h}$ prior to slaughter, showed increased levels of CK and LDH in blood, and high final $\mathrm{pH}$ in meat

lower temperatures increased the level of blood corticosterone,

higher temperatures increased the level of CK

meat of rabbits exposed to heat characterised with a low initial $\mathrm{pH}$ as a direct consequence of lactic acid accumulation 
Table 1 - contd.

\begin{tabular}{|c|c|c|}
\hline 1 & 2 & 3 \\
\hline María et al. (2006) & $\begin{array}{l}\text { Seasonality and envi- } \\
\text { ronmental conditions }\end{array}$ & $\begin{array}{l}\text { effect on } \mathrm{pH} \text { (measured } 24 \text { hours after slaughter) } \\
\text { water holding capacity } \\
\text { colour parameters }\left(\mathrm{L}^{*} \mathrm{a} * \mathrm{~b} *\right)\end{array}$ \\
\hline Voslarova et al. (2018) & $\begin{array}{l}\text { Seasonality and envi- } \\
\text { ronmental conditions }\end{array}$ & $\begin{array}{l}\text { transport at temperatures below } \\
-5^{\circ} \mathrm{C} \text { and above } 20^{\circ} \mathrm{C} \text { was correlated with the } \\
\text { highest death losses }\end{array}$ \\
\hline Verga et al. (2009) & Lairage & $\begin{array}{l}\text { mitigates the negative effect of transport on ani- } \\
\text { mals }\end{array}$ \\
\hline María et al. (2005) & Lairage & decrease in the corticosterone level \\
\hline Apata et al. (2012) & Stunning method & $\begin{array}{l}\text { all palatability traits were better in meat from rab- } \\
\text { bits stunned with gas } \\
\text { the most neutral method in the aspect of animal } \\
\text { welfare is gas stunning } \\
\text { the cooking loss, thermal shortening and drip loss } \\
\text { of meat were lower when the rabbits were stunned } \\
\text { with gas }\end{array}$ \\
\hline Nakyinsige et al. (2014) & Stunning method & $\begin{array}{l}\text { meat lightness ( } \mathrm{L}^{*} \text { value) was significantly higher } \\
\text { in meat stunned with gas, compared to those ex- } \\
\text { posed to the halal slaughter }\end{array}$ \\
\hline
\end{tabular}

\section{Rabbit farming system}

According to the Report of the Directorate-General for Health and Food Safety on Commercial Farming of Rabbits in the European Union (EU) (2017), rabbit systems in the EU are categorised into three main types: barren cages (conventional cages in production systems) accounting for around $85 \%$ of total EU production, enriched cages (accounting for 9\%) and the park-housing system (accounting for 6\%). Such housing standards are in agreement with the EU Directive 98/58/EC 1998 regarding the minimum conditions for the protection of animals kept for farming (Cullere and Dalle Zotte, 2018). In the EU, wire cages are the main housing system for breeding does and bucks. Wire cage floor space, without a nest box or platform, is approximately $50 \times 60 \mathrm{~cm}\left(0.33 \mathrm{~m}^{2}\right)$ and vertical space is $30-40 \mathrm{~cm}$. The wire cage sometimes has a foot mat. Adults are housed alone, does share their cage with their kits when the kits emerge from the nest box. Maximum stocking densities varied between EU member states. Densities ranged from $45 \mathrm{~kg} / \mathrm{m}^{2}$ to $50 \mathrm{~kg} / \mathrm{m}^{2}$ depending on how old animals were when the breeders sent them for slaughter (Commercial Rabbit Farming in the European Union, 2017) The conventional production system can provide for acceptable levels of feeding, health, and housing. The limited space availability due to cage sizes and stocking densities, limits normal rabbit behaviours such as standing, gnawing, and hopping. This situation is further aggravated in the smaller cages used for non-pregnant does. In these cages, does have difficulty even standing up or turning around (Tillmann et al., 2019). There are large cages available which are enriched with a platform, plastic foot mat and a gnawing block. The floor space is approximately $40 \times 90 \mathrm{~cm}\left(0.37 \mathrm{~m}^{2}\right)$, and the vertical space is $60 \mathrm{~cm}$. In some countries, there is an increasing recognition of the importance of space and enrich- 
ment for rabbit welfare, leading to a gradual transition to the park system (Dorning and Harris, 2017). In conventional and enriched systems, foot-rests are used to avoid injuries from continually sitting on a wire cage floor (Commercial Rabbit Farming in the European Union, 2017). There is an increased risk of injuries and foot problems in cages where wire-net flooring is used (De Jong et al., 2008). Alternative flooring systems are needed. It has been suggested by Szendrö et al. (2016) that the floor is one of the most important issues. Even if the risk of foot problems is marginal, wire net floors are considered to be linked to reduced physical comfort and restrict locomotor behaviours (Morisse et al., 1999). The popularity of the enriched housing systems is increasing. The pens are larger than cages, and can accommodate groups of 4-8 does with separate external nest boxes, platforms, and often enrichment items such as plastic feeding tubes, and gnawing blocks. Floor space together with the nest box is approximately $100 \times 200 \mathrm{~cm}\left(2.32 \mathrm{~m}^{2}\right)$, vertical space is open, and cages may be made from wire or more often, from plastic. In parks, does can escape their kits and socialise with other adults. Parks may also include an area where only kits can go. A disadvantage of the park housing system is that aggression between adults leads to increased mortality. The management of park systems is also more labour intensive compared to wire cages, as it requires more work to keep the pens clean (Dorning and Harris, 2017).

\section{Fasting}

Fasting before slaughter reduces the risk of contamination of the carcass during dressing. According to Jolley (1990) and Dalle Zotte (2002), the time of food restriction is important, because it affects the quality (ultimate muscle $\mathrm{pH}$ ), carcass yield (live weight loss), the safety of meat (spoilage and pathogenic bacteria), carcass contamination, and, of course, animal welfare. Fasting should not exceed 6-9 hours. After this period, energy reserves are depleted (Trocino et al., 2003). According to Cavani and Petracci (2004), during the first 12 hours of fasting, rabbits lose 3-6\% of their body weight. This weight loss increases to $8-12 \%$ at $36-48$ hours.

\section{Transport}

One of the factors having an undeniable influence on the quality of rabbit meat, is the stress associated with transport. Unfortunately transport is unavoidable as it is a part of the rabbit meat production chain (María et al., 2006). Transport may negatively affect the health and welfare of animals, leading to lower quality meat. There are regulations defining the conditions of rabbit transport: the Council Regulation (EC) No. 1/2005 of 22 December 2004 on the protection of animals during transport and related operations, Directives 64/432/EEC and 93/119/EC, and Regulation (EC) No 1255/97. During transport, animals are exposed to many factors, such as: the loading method (Mazzone et al., 2010; Buil et al., 2004), distance and travel time (Jolley, 1990; Trocino et al., 2003; Lambertini et al., 2006; Liste et al., 2008; María et al., 2006; Dal Bosco et al., 1997; Xiccato et al., 1994), stocking density (De la Fuente et al., 2004; Buil et al., 2004; Lambertini et al., 2006), lying during transport (Buil et al., 2004; Jolley, 1990), noise (De la Fuente et al., 2007), and environmental conditions (Liste et al., 2008; María et al., 2006). Commercial transport is also related to 
mortality of rabbits, and is affected by the distance, batch size, environment, and microclimate (Voslarova et al., 2018; Petracci et al., 2010; Marai and Rashwan, 2004).

\section{Loading method}

The loading method is one of the critical points that may influence animal welfare and final product quality (Buil et al., 2004). The most frequently bruised areas on the rabbit are the thoracic region, legs, and the inner loin. Unfortunately, the bruises become visible after the skin is removed (Verga et al., 2009). In their research, Mazzone et al. (2010) analysed the effect of two different loading methods (smooth and rough) on the quality of rabbit meat. They reported that $\mathrm{pH}$ values were not significantly affected by the loading method $(\mathrm{P}=0.697)$. In both groups the $\mathrm{pH}$ value was lower than 6.0, indicating good quality meat. The authors analysed the correlation between muscle enzymatic activity and meat $\mathrm{pH}$ to determine the effect of stress on meat quality. Moreover, Mazzone et al. (2010) found a correlation between LDH (lactate dehydrogenase) and $\mathrm{pH}$ (rough: $\mathrm{r}=0.41 ; \mathrm{P}<0.01$; smooth: $\mathrm{r}=0.44 ; \mathrm{P}<001$ ). Carcasses of rabbits loaded with the smooth method were characterised by smaller weight losses $(2.78 \%$ vs. $3.0 \%)$ and higher dressing percentages compared to the other groups of rabbits $(61.0 \%$ vs. $60.8 \%)$. To conclude, they observed that the loading method did not negatively affect the carcass and meat quality. Similarly, Vignola et al. (2008) found that stress parameters of transported rabbits were more influenced by the transport and handling, than by different loading methods. In Spain, Buil et al. (2004) focused on the critical points in the transport of commercial rabbits to the slaughterhouse. According to these studies, the loading method seems to have an important role in transport stress, but fortunately, that problem is well understood by the breeders.

\section{Distance and travel time}

Present animal welfare regulations set strict rules on transportation conditions, but even short-term transport can decrease the quality of meat (through depletion of glycogen reserves) (Jolley, 1990). To confirm the aforementioned thesis, Lambertini et al. (2006) reported that the transport time strongly affected live weight loss in rabbits. According to these authors, a $2 \mathrm{~h}$ journey resulted in a $\%$ weight loss, while the animals transported for $6-8$ hours had up to a $4 \%$ weight loss. According to Trocino et al. (2003), a 6-8 hour transport might lead to dehydration in rabbits. In their study, Liste et al. (2008) and María et al. (2006) analysed the same transport time (1 h and $7 \mathrm{~h}$ ). They reported that time did not affect the $\mathrm{pH}$ measurements.

As stated by Dal Bosco et al. (1997), meat of rabbits exposed to longer transport times had a higher $\mathrm{pH}$ as well as increased darkness and redness, compared to meat of rabbits transported for a shorter time. Similar results were obtained in the research of Trocino et al. (2003), but only the longissimus lumborum muscle revealed a decreased quality, no such effect of transport was noted on the biceps femoris muscle. Liste et al. (2008) found that transport time ( $1 \mathrm{~h}$ and $7 \mathrm{~h})$ affected the blood level of corticosterone and creatine kinase $(\mathrm{CK})$, confirming that transport is a source of stress for animals. They found that rabbits transported 4 hours prior to slaughter were characterised by a higher level of blood cortisol, glucose and triglycerides, and 
a lower insulin level, compared to the non-transported group. According to Maíra et al. (2006), time had a significant effect on the meat texture parameters $(\mathrm{P}<0.05)$, but did not affect the shear force and toughness. Conclusions similar to those of María et al. (2006) were found by Xiccato et al. (1994). Furthermore, the lowest mortality was found in rabbits transported over $50 \mathrm{~km}(0.02 \%)$ and from over 51 to $100 \mathrm{~km}$ $(0.05 \%)$ (Voslarova et al., 2018). The highest mortality was recorded for distances exceeding $400 \mathrm{~km}(0.29 \%)$. According to the Council Regulation (EC) No 1/2005 of 22 December 2004, food and water shall be available in adequate quantities (in the case of a journey lasting less than 12 hours and not including loading and unloading time). In conclusion, all authors showed a transport influence (which includes short distances as well as the amount of the transport on the quality of rabbit meat).

\section{Stocking density}

The research regarding the effect of transport conditions on animals is significant as far as the final product quality and animal welfare are concerned. De la Fuente et al. (2004) found that a stocking density of 53.6 or $37.0 \mathrm{~kg} / \mathrm{m}^{2}$ during transport did not influence the quality of rabbit meat. It was also reported by Lambertini et al. (2006) that there was no effect from even higher stocking densities of $75.5 \mathrm{~kg} / \mathrm{m}^{2}$ on the quality of rabbit meat transported from the farm to the slaughterhouse. The main problem during transport was the large variation and density of animals per cage. In Spain, where there are no regulations about space per rabbit, Buil et al. (2004) conducted research on animal density per cage. They recommended that minimum floor space for 12 week-old rabbits should be $1800 \mathrm{~cm}^{2}$.

\section{Lying during transport}

Rabbits are transported to slaughterhouses using a small two-axle trucks having an average floor area of $13.80 \mathrm{~m}^{2}$. The crates are placed in multi-level roller stands. According to Buil et al. (2004), the cage position during transport may affect the welfare of transported rabbits (Buil et al., 2004). It is necessary to constantly supervise the cage arrangement in the truck, and the environmental conditions prevailing in it (Buil et al., 2004). Excrements are listed among the most important factors negatively influencing transported rabbits. To prevent the drip of urine and faeces from higher levels of crates, Jolley (1990) suggested using solid floors in the transport of rabbits. According to the Council Regulation (EC) No 1/2005 of 22 December 2004 on the protection of animals during transport, leakage of faeces from the upper spaces to the lower ones should be limited and properly placed.

\section{Noise}

The development of civilisation has led to the widespread occurrence of anthropogenic noise. The noise may have serious implications for animals, as it may affect internal processes (e.g physiological processes such as blood pressure or immune response, sleep problems, fearfulness, and gene regulation) (Naguib et al., 2013). De la Fuente et al. (2007) focused on the physiological response of rabbits to noise, during transport. They reported that rabbits exposed to noise for $4.5 \mathrm{~h}$ prior to slaughter, showed increased levels of CK and LDH in their blood, and high final pH in their meat. 


\section{Seasonal and environmental conditions}

The study on the effect of environmental temperatures on the welfare of transported rabbits was conducted by Liste et al. (2008). The general average temperature in the summer was $27.16^{\circ} \mathrm{C}$, and in winter the average was $11.81^{\circ} \mathrm{C}$. The thermoneutral temperature zone for rabbits ranges from $10^{\circ} \mathrm{C}$ to $30^{\circ} \mathrm{C}$ (Animal Welfare Institute, 2004). Liste et al. (2008) found that lower temperatures increased the level of blood corticosterone, while higher temperatures increased the level of CK. In their study, they proved that even under optimal temperature conditions, the transport is a source of stress for rabbits. It was also reported by De la Fuente et al. (2007) that meat of rabbits exposed to heat is characterised by a low initial $\mathrm{pH}$ as a direct consequence of lactic acid accumulation. According to the research conducted by María et al. (2006), the transport time affects meat quality to a much lesser degree than does the time of year. The season had a significant effect $(\mathrm{P}<0.05)$ on $\mathrm{pH}$ (measured 24 hours after slaughter), water holding capacity, and all colour parameters ( $\mathrm{L}^{*} \mathrm{a} * \mathrm{~b} *$ ), but did not lead to the development of lower quality meat. Petracci et al. (2010) found a significant risk of death associated with low $\left(<7.3^{\circ} \mathrm{C}\right)$ and high $\left(\geq 22.6^{\circ} \mathrm{C}\right)$ environmental temperatures, during the transport process. Similar results were obtained by Voslarova et al. (2018), who found that transport in temperatures below $-5^{\circ} \mathrm{C}$ and above $20^{\circ} \mathrm{C}$ was correlated with the highest death losses, while the optimal temperature for rabbits ranges from $-5^{\circ} \mathrm{C}$ to $19.9^{\circ} \mathrm{C}$. To sum up, rabbits better endure low temperatures than high temperatures. In both cases, however, the productivity of rabbits can be improved by applying modern husbandry: changing stock density in cages, using air conditioning in the farms, adding vitamin $\mathrm{C}$ to the water as well as placing glass bottles filled with cold water in the cages, to be used during transport (Mousa-Balabel, 2004).

\section{Lairage}

After transport and arrival at the slaughterhouse, rabbits are unloaded from the truck and wait for slaughtering in designated holding pens, also referred to as lairage. This adaptation period minimises the consequences of transport stress and improves the rabbits' homoeostasis. Verga et al. (2009) found that lairing the rabbits at the abattoir for a few hours before slaughter can mitigate the negative effect of transport. Similar results were presented by María et al. (2005), who reported that 3 hours of lairage could be inadequate for the complete adaptation of the rabbits to stress (meat deterioration could result). They have found that keeping rabbits in an enclosed area for 6 hours after transportation, mitigates the effect of transportation stress and leads to a decrease in the corticosterone level. The producers and breeders of rabbit meat should, if possible, limit or avoid transporting these animals.

\section{Stunning method}

Stunning is one of the most important slaughtering procedures in the production of meat. In 2009, the EU accepted the Council Regulation (EC) 1099/2009, concerning animal stunning and slaughter. The main goal is to minimise the suffering and pain of animals. There are various stunning methods, including electrical, mechanical, and gas stunning (Apata et al., 2012). The European rabbit slaughterhouses use 
the electrical stunning method. The most frequently used values of voltage and power are $49 \mathrm{~V}$ and $250 \mathrm{~Hz}$. Rabbits receive an electroshock lasting less than 2 seconds, in the frontal sinus (Fossa temporalis) with a "V" shaped metal electrode (López et al., 2008). Three different combinations of voltage and power values in electrical stunning of rabbits were analysed by Lafuente and Lopez (2014). Besides the most commonly used magnitude of voltage, and frequency measuring $49 \mathrm{~V}$ and $250 \mathrm{~Hz}$, they also examined the combination of high voltage $(130 \mathrm{~V})$ with low frequency $(172 \mathrm{~Hz})$, and low voltage $(22 \mathrm{~V})$ with high frequency $(833 \mathrm{~Hz})$. High voltage and frequency may be better than medium voltage and frequency levels with the aim to improve eating quality (tenderness and juiciness). Slight differences were noticed by María et al. (2005) in the $\mathrm{pH}$ value of meat from animals stunned with the electrical method, when using different frequencies. Lafuente and Lopez (2014) compared the effect of mechanical and electrical stunning on rabbit meat. The $\mathrm{pH}$ of muscles 24 hours post-mortem from mechanically stunned rabbits was lower compared to the electrically stunned animals. López et al. (2008) found that the value of $\mathrm{pH}$ measured 24 hours post-mortem was lower in meat from animals submitted to halal slaughter compared to those electrically stunned. The authors concluded that the high $\mathrm{pH}$ value of meat from ritually slaughtered rabbits could have been the result of lower lactic acid content in the muscles post-mortem. According to Devine et al. (2004), mechanical stunning entails the use of either a hammer, a captive bolt, or a narrow rod. Captive bolt stunning may be penetrative or non-penetrative. Both methods rely on the outcome of instantaneous and massive disruption of brain function to render the animal unconscious (Devine et al., 2004). This method of stunning is performed by trained operators who are able to monitor the signs of an effective stun for each animal. Another method is gas stunning. It is based on the use of properly balanced gas dives. Apata et al. (2012) stunned rabbits with diethyl ether poured on a large quantity of cotton wool in a desiccator, and each rabbit was placed in the desiccator for $15 \mathrm{sec}$. (Apata et al., 2012). When using industrial gas mixtures, the animal is placed in the slaughter chamber and given a mixture of gases with different proportions of oxygen, carbon dioxide $\left(\mathrm{CO}_{2}\right)$, nitrogen, and argon, in a single-phase or two-phase sequence. When using the single-phase method, the oxygen content in the mixture is low (below 2\%). In the two-phase method the first phase includes the application of the gas mixture (e.g. $40 \% \mathrm{CO}_{2}$ and $30 \%$ nitrogen and oxygen) causing the animal to be anaesthetised. In the second phase, $\mathrm{CO}_{2}$ is increased to $80 \%$, and there is a lack of oxygen, which leads to the animal's death (Skrabka-Błotnicka, 2012). According to Apata et al. (2012), all palatability traits were better in meat from rabbits stunned with gas. As far as animal welfare is concerned, it is the most neutral method. Moreover, gas stunning is accepted by animal welfare organisations and governments across Europe (Gerritzen et al., 2013). Halal slaughter is still considered controversial, due to the lack of stunning before bleeding. However, when López et al. (2008) compared electrical stunning to the halal slaughter, they found that under appropriate conditions, the performance of the halal slaughter does not negatively affect animal welfare or even instrumental meat quality characteristics. Moreover, Nakyinsige et al. (2014) compared the effect of halal slaughter and gas stunning on the welfare of rabbits. The researchers used carbon dioxide $\left(\mathrm{CO}_{2}\right)$, which is an alternative stunning 
system used on pigs, poultry, sheep, and rabbits. It was reported by Nakyinsige et al. (2014) that there were no statistical differences in meat $\mathrm{pH}$ values between rabbit groups stunned using different methods. They also reported a significantly greater meat lightness ( $\mathrm{L}^{*}$ value) in rabbits stunned with gas, compared to those exposed to the halal slaughter. It was found by Dal Bosco et al. (1997) that there was an effect of the stunning method on the meat $\mathrm{pH}$ value, but not on the colour coordinates. According to the study of Apata et al. (2012), the cooking loss, thermal shortening, and drip loss of meat were lower when the rabbits were stunned with gas $(\mathrm{P}<0.05)$ compared to the electrically stunned animals. The results presented by Nakyinsige et al. (2014) indicate that cooking loss was significantly lower in the meat of rabbits from the halal slaughter compared to the animals stunned with gas. Apata et al. (2012) found that a high moisture content in the meat of electrically stunned rabbits contributes to a higher drip and cooking loss. Moreover, they observed that rabbits stunned with gas had a higher content of protein and nitrogen free extract, and lower $\mathrm{pH}$ value, compared to animals stunned by other stunning methods $(\mathrm{P}<0.05)$. There were no differences in fat and ash content between all the observed groups of rabbits. Dal Bosco et al. (1997) and Van der Wal et al. (1983) concluded that the rabbit meat production chain is very complex, with numerous factors affecting the water factions and capacity of muscle tissue to hold residual water. This makes it difficult to determine the true effect of the stunning technique on the mentioned traits.

\section{Conclusion}

The principles of animal welfare should be respected in all phases of the production chain, and during all technological activities carried out on animals. This is particularly true in the pre-slaughter welfare, which is considered crucial to the production of high quality rabbit meat (Table 1). This review should be used by the rabbit meat producers and rabbit breeders, and should result in the development of non-invasive methods for measuring stress levels so production can be improved. It has been demonstrated that European consumers will pay more for a product from farms with good farming and pre-slaughter practices. However, because of the complexity of the rabbit meat production chain, the possibilities of excluding all the preslaughter factors that negatively affect rabbit welfare, are limited.

\section{References}

A pat a E.S., Eniolorunda O.O., A ma o.E., Okubanjo A.O. (2012). Quality evaluation of rabbit meat as affected by different stunning methods. Int. J. of Agric. Sci., 2: 54-58.

B u il T., Mari a G.A., Villarroe 1 M., L is te G., L o pe z M. (2004). Critical points in the transport of commercial rabbits to slaughter in Spain that could compromise animals' welfare. World Rabbit Sci., 12: 269-279.

C a v a n i C., P e tra c c i M. (2004). Rabbit meat processing and traceability. Proc. XVIII World Rabbit Congress, Puebla, Mexico, 7.10.2004, pp. 1318-1336.

Cullere M., Dalle Zotte A. (2018). Rabbit meat production and consumption: State of knowledge and future perspectives. Meat Sci., 143: 137-146.

Da 1 B o s co A., Cast ell in i C., B ernardini M. (1997). Effect of transportation and stunning method on some characteristics of rabbit carcasses and meat. World Rabbit Sci., 5: 115-119. 
Da 11 e Z ot te A. (2002). Perception of rabbit meat quality and major factors influencing the rabbit carcass and meat quality. Livest. Prod. Sci., 75: 11-32.

De Jong I.C., Reimert H., R o m mers J.M. (2008). Effect of floor type on footpad injuries in Does. Proc. IX World Rabbit Congress, Verona, Italy, pp. 1171-1176.

De la Fuente J., S a lazar M.I., Ibáñez M., de Chavarri E.G. (2004). Effects of season and stocking density during transport on live weight and biochemical measurements of stress, dehydration and injury of rabbits at time of slaughter. Anim. Sci., 78: 285-292.

De la Fuente J., Díaz M.T., Ibáñez M., González de Chavarri E. (2007). Physiological response of rabbits to heat, cold, noise and mixing in the context of transport. Anim. Welf., 16: $41-47$.

D e vin e C., J e n s e n W.K., D i k e m a n M. (2004). Encyclopedia of Meat Sciences. Academic Press, pp. $405-425$.

D o k t o r J. (2007). Effect of preslaughter handling on carcass and meat traits in chickens (in Polish). Wiad. Zoot., 45: 25-30.

Dorning J., Harris S. (2017). The welfare of farmed rabbits in commercial production systems. Technical Report; doi: 10.13140/RG.2.2.24874.41925.

Gerritzen M.A. R e i m er t H.G.M., Hind le V.A., Verho even M.T.W., Ve erka mp W.B. (2013). Multistage carbon dioxide gas stunning of broilers. Poultry Sci., 92: 41-50.

$\mathrm{Hu}$ g h e s B.O. (1976). Behaviour as an index of welfare. Proc. V European Poultry Conference, Malta, pp. 1005-1018.

J o 11 e y P.D. (1990). Rabbit transport and its effects on meat quality. Appl. Anim. Behav. Sci., 28: $119-134$.

L a fu en te R., Ló pe z M. (2014). Effect of electrical and mechanical stunning on bleeding, instrumental properties and sensory meat quality in rabbits. Meat Sci., 98: 247-254.

L a mbertini L., Vignola G., B a di ani A., Zaghini G., Formigoni A. (2006). The effect of journey time and stocking density during transport on carcass and meat quality in rabbits. Meat Sci., 72: 641-646.

L is te M.G., Maria G.A., Garcia-B elenguer S., Chacon G., Gazzola P., Villarroe 1 M. (2008). The effect of transport time, season and position on the truck on stress response in rabbits. World Rabbit Sci., 16: 229-235.

Ló pe z M., Carril ho M.C., C a m p o M.M., L a fu e n te R. (2008). Halal slaughter and electrical stunning in rabbits: effect on welfare and muscle characteristics. Proc. IX World Rabbit Congress, Verona, Italy, 10-13.06.2008, pp. 1201-1206.

Marai I.F.M., Ras hwan A.A. (2004). Rabbits behavioural response to climatic and managerial conditions - a review. Arch. Anim. Breed., 47: 469-482.

María G.A., Villarroel M., Lis te G., Buil T., Chacón G., Sañudo C., Olleta J.L., García Berenguer S., A lierta S. (2005). Effect of lairage duration on welfare and meat quality in Spanish commercial rabbits. NJF Report, 1: 41-51.

María G.A., Buil T., Liste M., Villaroel M., S anudo C., Olleta J.L. (2006). Effect of transport time and season on aspects of rabbit meat quality. Meat Sci., 72: 773-777.

Mazzone G., Vignola G., Giammarco M., Manetta A.C., La mbertini L. (2010). Effects of loading methods on rabbit welfare and meat quality. Meat Sci., 85: 33-39.

Morisse J.P., B oille tot E., Martrenchar A. (1999). Preference testing in intensively kept meat production rabbits for straw on wire grid floor. Appl. Anim. Behav. Sci., 64: 71-80.

Mous a-B a la b e 1 T.M. (2004). Effect of heat stress on New Zealand White rabbits behavior and performance. Minufiya Vet. J., 3: 125-134.

Naguib M., Van Oers K., Braakhuis A., Griffioen M., De Goede P., Waas J.R. (2013). Noise annoys: effects of noise on breeding great tits depend on personality but not on noise characteristics. Anim. Behav., 85: 949-956.

Nakyinsige K., Sazili A.Q., Zulkifli I., Goh Y.M., Bakar F.A., Sabow A.B. (2014). Influence of gas stunning and halal slaughter (no stunning) on rabbits welfare indicators and meat quality. Meat Sci., 98: 701-708.

Petracci M., Bianchi M., Biguzzi G., Cavani C. (2010). Preslaughter risk factors associated with mortality and bruising in rabbits. World Rabbit Sci., 18: 219-228.

Skrabka-Błotnicka T. (2012). Methods of dazing slaughter animals (in Polish). Nauki Inż. Techn., 1: 55-69. 
S zendrö Z.S., M c N it t J.I., M a ti c s Z.S., M i k o A., Geren c s er Z.S. (2016). Alternative and enriched housing systems for breeding does: a review. World Rabbit Sci., 24: 14.

Tillmann K., Wind s chnurer I., G a m per J., H inney B., Rüli cke T., P od es ser B.K., Trox ler J., P l a s e n z o t t i R. (2019). Welfare assessment in rabbits raised for meat and laboratory purposes in enclosures with two floor types: Perforated plastic with holes versus slats. Vet. Sci., 122: 200-209.

Trocino A., Xiccato G., Que a que P.I., Sartori A. (2003). Effect of transport duration and gender on rabbit carcass and meat quality. World Rabbit Sci., 11: 23-32.

Verga M., Luzi F., Petracci M., C a vani C. (2009). Welfare aspects in rabbit mat rearing and transport - review article. Ital. J. Anim. Sci., 8: 191-204.

Vignola G., Giammarco M., Mazzone G., Angelozzi G., Lambertini L. (2008). Effects of loading method and crate position on the truck on some stress indicators in rabbits transported to the slaughterhouse. Proc. IX World Rabbit Congress, Verona, Italy, 10-13.06.2008, pp. 1257-1262.

Vos larova E., Vecerek V., B edanova I., Vecerkova L. (2018). Mortality in rabbits transported for slaughter. Anim. Sci. J., 89: 931-936.

Xiccato G., Parigi-Bini R., Dalle Zotte A., Carazzolo A. (1994). Effect of age, sex and transportation on the composition and sensory properties of rabbit meat. Proc. XL International Congress of Meat Science and Technology, p. 52.

Received: 6 II 2019

Accepted: 14 VI 2019 